\title{
The Development of Housing in Mexico: A Welfare Regime Approach
}

\author{
Ricardo Velázquez Leyer
}

Department of Social and Policy Sciences, University of Bath

E-mail: rvl20@bath.ac.uk

Housing represents a basic human need. Families can access housing through public policy, market mechanisms or by their own resources. This article adopts a welfare regime approach to analyse the housing sector in Mexico. The objective is to map the Mexican housing regime and to reveal its major outcomes. The study reveals the roles that public policy, markets and families have played for housing provision in the country's recent history. Findings show that whilst recent policy changes have enhanced the government's intervention in the housing sector, they have reproduced the unequal and fragmented nature of the country's social policy, and their design based on a market rationale has not resolved the housing needs for the majority of the population. The state and markets fail to provide adequate support for the majority of Mexican families, which continue to bear the heaviest responsibility for housing provision.

Keywords: Mexico, social policy, housing, welfare regime, neoliberalism.

\section{Introduction}

Housing represents a fundamental source of welfare for families, it is the centre of family life, the realm where the family develops, and in many cases it constitutes its main patrimony (Alcock et al., 2003; Allen et al., 2004). Families can access housing through government interventions, private sector instruments or resources that they raise by themselves. Under a welfare regime approach, the interactions of these three spheres, namely the welfare mix, and their outcomes make up a country's particular housing regime (Kemeny, 2006; Norris and Winston, 2012). This article aims to map the Mexican housing regime by establishing the extent to which the state, markets and families are responsible for housing provision, and identifying the major outcomes that the interactions between the three spheres have generated during the country's recent history.

The article is divided into four sections. The first summarises current depictions of the Mexican welfare regime. The second provides a historical review of the development of housing in Mexico. The third outlines the Mexican housing regime, identifying the role that the state, markets and society have played in housing provision over recent decades, and establishes the regime's major outcomes in terms of the access to and quality of housing for different sectors of the population. The fourth and final section offers some concluding remarks.

\section{The Mexican welfare regime and housing}

The welfare regime of Latin America has been described as 'conservative' up to the 1980s and 'liberal' after that decade, ${ }^{1}$ with a large informal economy in both phases 


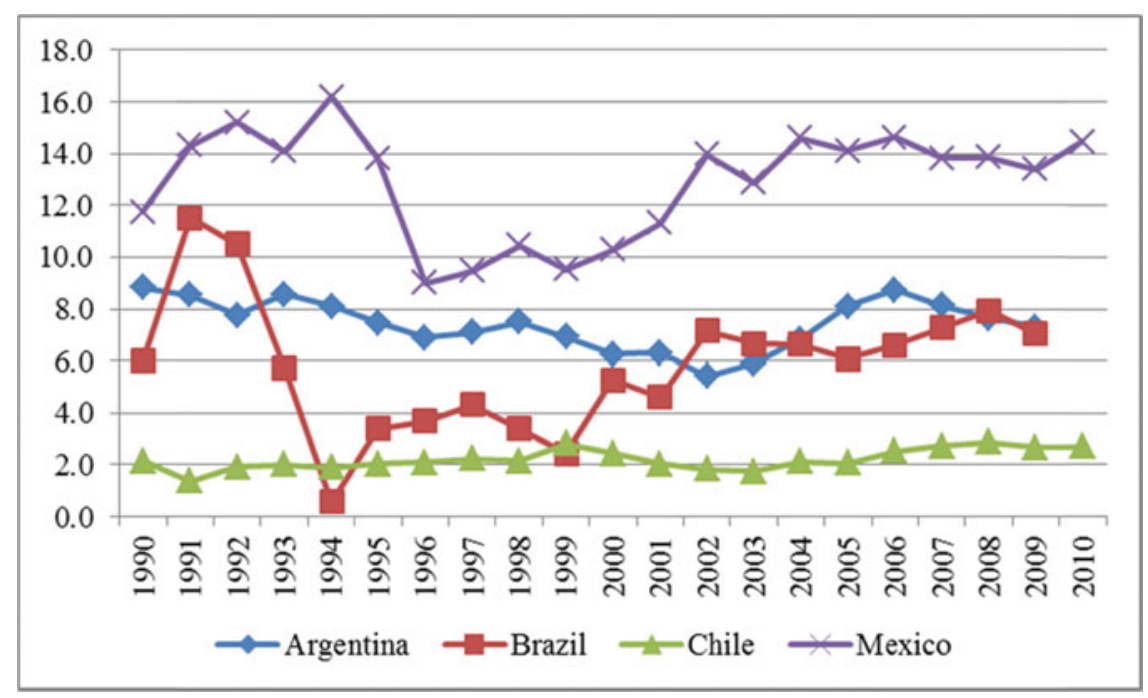

Figure 1. (Colour online) Spending on housing as a percentage of total social spending, 1990-2011 Source: Author's own elaboration with data from CEPAL (2013).

(Barrientos, 2004, 2009). Characterisations of the Mexican regime coincide with this depiction. In the context of an authoritarian hegemonic party regime and an economic model of industrialisation through import substitution (ISI), welfare provision was based on stratified social insurance for workers in formal employment (Barba et al., 2007; Dion, 2010). Families were covered insofar as their breadwinner was insured. Social insurance was less stratified than in other Latin American countries (Mesa-Lago, 2000), but spending was kept at lower levels (Hansen, 1971) and the programmes expanded at a slow pace, only reaching half of the population by the 1980s (Filgueira and Filgueira, 2002; Dion, 2010). Given the limited scope of social policy, families carried the heaviest burden of welfare provision, with a minor role played by markets (Brachet-Marquez and De Oliveira, 2002).

After the 1980s, political and economic liberalisation triggered and shaped social policy reforms (Dion, 2010). These reforms have placed market mechanisms at the core of welfare provision, introduced cuts to social insurance programmes and expanded the role of social assistance policies, pushing the country towards a 'liberal' regime (Brachet-Marquez, 2007; Bayón, 2009). Changes have not relieved families of welfare responsibilities (Brachet-Marquez and De Oliveira, 2002; Bayón, 2009) and in some cases have even increased them, as the design of new policy instruments has relied on the traditional role played by women in Mexican society (Molyneux, 2006).

Recent characterisations of Mexico's welfare regime have not considered the central space that housing occupies in the country's social policy. The Mexican government gives a higher priority to housing spending than governments of other Latin American countries. Figure 1 shows that spending on housing as a percentage of total social spending was much higher for every year since 1991 than in Argentina, Brazil and Chile. In fact, according to data from the Economic Commission for Latin America and the Caribbean (CEPAL), up until the mid-1990s the Mexican government was spending more on housing 
than on social security - 16.2 per cent of total social spending on the former, compared to 13.5 per cent on the latter in 1994 (CEPAL, 2013).

\title{
The development of housing in Mexico
}

\author{
1930s-1960s: minimal state intervention
}

The Constitution enacted in 1917 had established the obligation for employers to provide housing for their employees; but like other social dispositions, policies to fulfill this obligation would take decades to be implemented (De Pablo, 2000; Brachet-Marquez, 2007; García Peralta, 2010). During the first decades, the government began providing soft loans to public sector workers and investing in social housing, developing housing projects and letting the units; but these actions would be largely symbolic and would not have any significant impact compared with the needs of the country (Brachet-Marquez, 2007; García Peralta, 2010). Between the 1940s and 1960s, only 9,500 new homes a year were provided with state support (Bredenoord and Verkoren, 2010),

Social housing was abandoned in the early 1960 s because the focus of public policy became the promotion of private property to combat socialist pressures (García Peralta, 2010). The government created a trust fund within the central bank, called the Housing Banking Finance and Operation Fund (FOVI), to channel resources for the acquisition and construction of homes through private banks (De Gortari and Ziccardi, 1996; De Pablo, 2000), but only middle and upper class families would benefit from it, since private loans were unaffordable for the majority of poor families (Rodriguez and Maycock, 2006; García Peralta, 2010).

The main option for poor families became self-built housing in irregular settlements. The combination of fast population growth rates, rural-urban migration and urbanisation, ${ }^{2}$ and the low levels of public intervention generated the emergence of irregular settlements on the peripheries of the cities, where families built their own homes with precarious materials (CIDOC, 2004; Rodriguez and Maycock, 2006; Platt, 2010; Bredenoord and Verkoren, 2010). This process was enabled by three factors. First, the availability of land due to the illegal trade of rural communal land and direct invasions, with the collusion of public officials (Shefner, 2001; Rodriguez and Maycock, 2006). Secondly, clientelistic negotiations between the settlers and local governments, through the hegemonic party regime, the only valid intermediary between the poor and municipal governments (Langston, 2002). The settlers demanded, and usually obtained, land titles and public services, conditional on their support for the political regime (Shefner, 2001; Rodriguez and Maycock, 2006). Thirdly, the need for a cheap workforce to develop domestic industries, as self-built housing in irregular settlements kept demands for wage increases under control, since families did not have to pay rent, and allowed employers to pay fewer taxes since the government did not have to invest large sums in public infrastructure (Platt, 2010).

\section{0s-1980s: the institutionalisation of housing policy}

At the beginning of this period, the government responded to mounting social pressures by expanding social policy. The high economic growth rates achieved during the previous decades had not resulted in significant reductions in poverty and inequality, which 
triggered social and political tensions (Hansen, 1971; Brachet-Marquez, 2007; Dion, 2010). Housing was placed at the centre of the government's response (Brachet-Marquez, 2007; García Peralta, 2010).

Two housing institutes were created. The cornerstone of housing policy in Mexico was the creation of the Workers' Housing Fund National Institute (INFONAVIT) in 1972, to grant soft loans to formal private sector workers for the purchasing, construction or upgrading of housing units. INFONAVIT was put in charge of planning and coordinating housing developments, but the construction process was subcontracted to private companies (Puebla Cadena, 2006; Bredenoord and Verkoren, 2010; García Peralta, 2010).

INFONAVIT was conceived as a social insurance model, the same logic as applied in the design of the main social programmes. It had a tripartite administration with representatives from officially recognised trade unions, employers' organisations and the state. It was funded by a payroll tax of 5 per cent of wages paid entirely by employers, who did not oppose it because in a closed economy such as Mexico had under the ISI model, the cost could be passed on to the final consumer (Brachet-Marquez, 2007). The design of INFONAVIT, under social insurance logic, meant that coverage was limited to waged workers in formal employment, excluding groups like the self-employed, informal sector workers and peasants.

INFONAVIT would represent an important boost to housing production, but its operation was marked by clientelistic and corrupt practices. Housing policy during this phase was used for political cooptation and control (García Peralta, 2010). The process for the allocation of loans was controlled by trade union leaders, who tended to favour their own union members to help secure political control (Martinez, 2003). At the same time, union leaders, along with public officials and business leaders involved in INFONAVIT's administration, benefited by creating their own private companies, to which the construction of housing projects was sub-contracted (Brachet-Marquez, 2007; García Peralta, 2010).

Housing loans for public sector workers were reorganised and grouped under a unique fund called the Housing Fund of the State Workers' Social Security and Services Institute (FOVISSSTE), also in 1972. This fund was designed along the same lines as INFONAVIT, but with more generous loan conditions (De Gortari and Ziccardi, 1996; Puebla Cadena, 2006; Bredenoord and Verkoren, 2010). Separate smaller funds were created for the military and workers of the state oil and electricity companies (INEGI, 2010).

For families of workers who were not in formal employment, many of them living in precarious homes in irregular settlements, the government introduced subsidies for selfbuilt solutions. The National Fund for Popular Housing (FONHAPO) was created in 1981, to offer subsidies for the construction or upgrading of homes (De Gortari and Ziccardi, 1996; CIDOC, 2004; Puebla Cadena, 2006; Bredenoord and Verkoren, 2010). As in other social assistance programmes implemented during that period, clientelism was pervasive in FONHAPO's operation (Paladino, 2010).

Irregular settlements continued to be a common option for many poor families, but the 1970s marked the institutionalisation of the government's intervention in the housing sector. INFONAVIT and FOVISSSTE increased the number of public housing loans granted in the country from 51,000 in 1973 to more than 250,000 by the mid-1980s (Brachet-Marquez, 2007; INEGI, 2010); but the process was conducted with high levels of clientelism, corruption and inequality. Access to government programmes depended to 
a large extent on corporatist/clientelistic arrangements developed to guarantee social and political control. At the same time, an unequal system had been created, with stratified benefit levels for different population groups.

During the last decade of this period, the economic crisis of 1982 eroded INFONAVIT's resources due to a combination of high inflation and the low interest rates at which loans were granted (García Peralta; 2010), and FONHAPO was almost completely phased out due to the cancellation of foreign funding and the decentralisation of its activities to local governments (Connolly, 1997; Puebla Cadena, 2006).

1990s-2000s: market-centred reforms

Three groups of reforms can be identified during this period. INFONAVIT was reformed in 1992, with the aims of improving its efficiency, making the allocation of loans and the administration of funds more transparent and offering workers a wider choice of homes (García Peralta, 2010). An individual account was opened for every worker to keep track of their contributions, and a system of points was created to allocate loans based on the account balance, age, wage and years of contributions. INFONAVIT had to pay return rates on the resources deposited in individual accounts higher than the annual increase of the minimum wage. Workers could then use their individual account balance as a first payment to buy a home, with INFONAVIT providing the remaining amount as a mortgage loan with low interest rates (LINFONAVIT, 1992).

At the same time, INFONAVIT withdrew from the sub-contracting of companies for the construction of housing projects. Loans now had to be used to purchase homes directly from private constructors. The institute was transformed into a financial institution for the provision or facilitation of mortgage loans. FOVISSSTE was reformed along similar lines. In this way both institutions became mere facilitators of credit with no further responsibility over housing planning or production (CIDOC, 2004; Puebla Cadena, 2006; Bredenoord and Verkoren, 2010; García Peralta, 2010).

The second group of reforms consisted of the enhancement of the role of the private sector. In the early 1990s the country experienced a boom in private mortgage lending as commercial banks enjoyed abundant liquidity due to the liberalisation of the economy. However, when another economic crisis hit the country in 1995, increases in interest rates and irresponsible lending practices were two of the factors that led to their collapse. The government rescued the banks, but private financing for housing came to a halt (Babatz, 2004; García Peralta, 2010).

To boost private lending again, the government promoted the creation of specialised private mortgage banks called Sociedades Financieras de Objeto Limitado (SOFOLs), whilst the FOVI, created in the 1960s, was transformed into the Federal Mortgage Society (SHF). To capitalise the SOFOLs, the SHF borrowed money from the social insurance pension funds, which had been privatised in 1997, and the banks then lent the money to the public. This process provided an abundant flow of resources for the financing of housing (Babatz, 2004). INFONAVIT and FOVISSSTE introduced joint loan schemes with the SOFOLs as well as with commercial banks (Puebla Cadena, 2006; Bredenoord and Verkoren, 2010). A second way in which the government promoted the role of private mechanisms was by financing the operation of private construction companies. This process was also conducted through the SHF and the SOFOLs. The SHF began lending 
money to the SOFOLs, so that they could in turn lend it to private constructors (Babatz, 2004).

The two groups of reforms triggered an increase in the number of housing loans funded by INFONAVIT, FOVISSSTE, SHF and private financial institutions, from 188,000 in 1990 to 832,000 in 2012 (INEGI, 2013), but they also generated considerable negative effects. INFONAVIT's reforms neglected the needs of the poorest workers. During the 1980s, 83 per cent of workers that received funding from this institute earned up to twice the minimum wage; during the 1990s the proportion decreased to only 23 per cent (García Peralta, 2010), and by 2004 the average wage of workers who obtained loans was six times the minimum wage, whilst 60 per cent of covered workers actually earned less than three times the minimum wage (Puebla Cadena, 2006). The reforms privileged middle and upper income workers by setting the individual account balance and the wage as criteria to establish eligibility for a loan.

Additionally, the withdrawal of INFONAVIT and FOVISSSTE from the planning of housing projects provoked disorganised growth of urban areas. The land counter-reform of 1992 authorised the commercialisation of rural communal land. Land close to urban areas could now be bought legally by private constructors, unlike in previous decades when it was traded on the black market. To maximise their profits, constructors began to buy land further away from urban centres because it was cheaper, although it lacked services like water and electricity and there were no adequate roads or means of transportation to access it (Puebla Cadena, 2006). Between 1980 and 2010, the urban population of the country doubled, but the urban footprint increased seven times (Herbert et al., 2012). The poor location of the new housing developments represented severe problems for the families that inhabited them (Puebla Cadena, 2006; SHF/CIDOC, 2012).

The reforms in housing funding and construction also left the sector vulnerable to market forces. The government's weak regulatory framework allowed the SOFOLs to engage in risky construction and mortgage lending practices, which eventually led them into severe liquidity problems, especially after the global financial crisis of 2008 . $^{3}$ Private constructors also suffered, not only due to the economic downturn, but because the bad location of housing developments decreased demand. The financial troubles of construction companies meant that they could not meet their obligations towards the SOFOLs, further aggravating the liquidity problems of the latter. By 2012, practically all the SOFOLs and the major private constructors had declared, or were close to declaring, bankruptcy (Herbert et al., 2012; SHF/CIDOC, 2012).

The third group of reforms was the expansion of targeted subsidies for the low income population. Social assistance programmes had existed in the past, but this time they were larger in scope, more institutionalised and less clientelistic (Dion, 2010; Paladino, 2010; Diaz-Cayeros et al., 2012). FONHAPO was revamped in the early 2000s, turning it again into one of the federal government's core housing programmes (Puebla Cadena, 2006). During its previous incarnation, FONHAPO's subsidies had peaked at 61,000 in 1988; in the new version, they rose from 21,000 in 2000 to 278,000 in 2006 (INEGI, 2013).

An additional programme of subsidies for poor families was introduced by another government agency, called the National Housing Commission (CONAVI), in 2007. These subsidies were meant to complement mortgage loans obtained from one of the public institutes or a private financial institution (SHF/CIDOC, 2012), so only families that had already obtained a loan could receive them. 


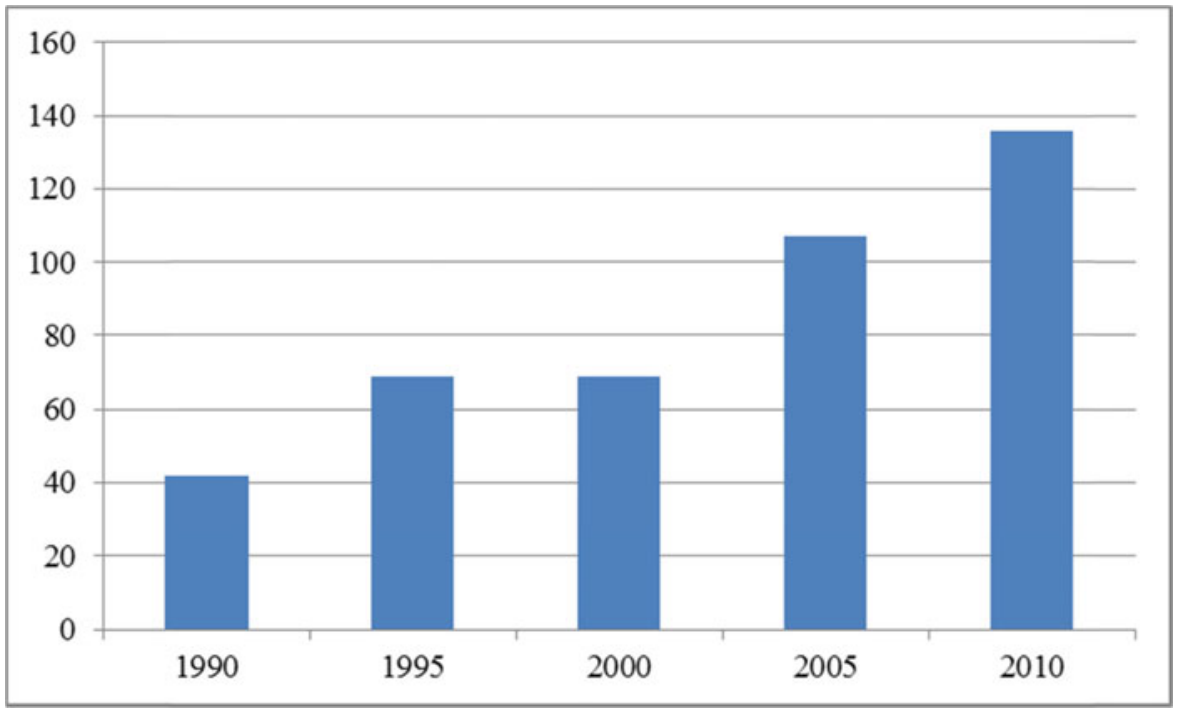

Figure 2. (Colour online) Per capita public spending on housing in Mexico, 1990-2010* Notes: *Amounts in 2005 US Dollars.

Source: CEPAL (2013).

\section{The Mexican housing regime}

\section{A fragmented and unequal public policy}

Housing policy has taken different shapes throughout recent history. After an initial phase of minimal state intervention came the institutionalisation phase when the housing funds were created. INFONAVIT and FOVISSSTE represented a great step for housing policy, but their growth was slow, and by 1989 both funds together were granting no more than a total of 100,000 loans. Even adding FONHAPO's subsidies, which amounted to 45,000, the impact of public policy by that year was extremely limited considering that the country had more than 16 million homes (INEGI, 2010). Moreover, the housing programmes operated with clientelistic practices, as they were used to maintain social and political control.

Subsequent reforms made housing policy more transparent and less clientelistic, and did result in a significant increase in the number of government loans and subsidies, which reached 765,000 in 2012. Figure 2 shows how by 2010 the government was spending more than triple the amount on housing per citizen than in 1990 (CEPAL, 2013). However, in spite of the growth, the reforms reproduced a high degree of inequality.

Up to the 1980s, Mexican social policy was characterised by its dual nature (Filgueira and Filgueira, 2002), with formal sector workers and their families receiving most benefits delivered through social insurance programmes, whilst little was offered to the rest of the population (Barba et al., 2007; Dion, 2010). Although introduced much later than social insurance programmes, housing policy mirrored their 'truncated' and unequal nature. Government action on housing focused exclusively on formal sector employees too, and neglected the needs of the rest of the population. In the early 1970s less than 30 per cent of the labour force was covered by social insurance (Carrillo Castro, 1987; IMSS, 2013; 
Table 1 Distribution of public loans and subsidies (\% of total)

\begin{tabular}{ccccc}
\hline \hline Year & INFONAVIT & FOVISSSTE & FONHAPO & Total \\
\hline \multirow{2}{*}{2000} & Loans & & & \\
2005 & 89.0 & 8.5 & 2.5 & 100 \\
2010 & 63.9 & 8.5 & 27.6 & 100 \\
2012 & 66.4 & 12.7 & 20.8 & 100 \\
& 75.8 & 8.4 & 15.8 & 100 \\
2000 & Spending & & & \\
2005 & 91.4 & 7.4 & 1.2 & 100 \\
2010 & 81.7 & 16.1 & 2.2 & 100 \\
2012 & 73.9 & 24.5 & 1.6 & 100 \\
\hline \hline
\end{tabular}

Source: INEGI (2012).

INEGI, 2013), so when the housing institutes were created, they could only benefit at most one third of the population.

In recent decades social policy has been expanded to reach population groups that had been traditionally excluded. This expansion has been carried out through targeted social assistance programmes (Dion, 2010). In the case of housing policy, FONHAPO represents the social assistance programme by which the government has attempted to offer benefits to families without social insurance. The implementation of programmes like FONHAPO means that the 'truncated' nature of Mexican social policy has been breached to a certain degree, but its unequal features persist.

FONHAPO's subsidies represent the largest share of the increase in the number of benefits directly provided by public programmes during the last decade. If the loans or subsidies provided by INFONAVIT, FOVISSSTE and FONHAPO are added together, FONHAPO's subsidies move from representing 2.5 per cent of the total in 2000, to more than 20 per cent in 2005 and 2010. The top rows of Table 1 show the distribution of loans between the three programmes, the bottom rows compare the distribution of spending. FONHAPO's spending did not increase in proportion to the other two funds, peaking at 2.2 per cent in 2005.

Even after the recent expansion of social assistance programmes like FONHAPO, social policy in Mexico continues to be highly unequal. In 2012, INFONAVIT and FOVISSSTE covered roughly 35 per cent of the workforce (INEGI, 2013). This means that 98 per cent of the resources spent on programmes that provide direct housing benefits are concentrated on that sector of the population. For the housing needs of the workers not covered by INFONAVIT or FOVISSTE, the government spent only 1.7 per cent. FONHAPO's subsidies cannot have a strong impact because of their low spending levels and meager benefit amounts (Puebla Cadena, 2006).

CONAVI's subsidies have not reversed this unequal distribution of resources. In 2012, spending on this programme represented only 6 per cent of INFONAVIT's expenditure (INEGI, 2012). Moreover, 66 per cent of that amount actually complemented INFONAVIT or FOVISSTE loans. Hence, even considering CONAVI's spending as part of the distribution, the resources spent on that part of the population not covered by 
INFONAVIT or FOVISSSTE, which represents 65 per cent of the labour force, would not surpass 3 per cent of spending (CONAVI, 2013).

Inequalities also persist between private and public sector workers. The latter have been traditionally regarded as enjoying more generous welfare benefits (Dion, 2010). To provide housing, public loan schemes for civil servants were introduced from the 1920s (De Gortari and Ziccardi, 1996), decades earlier than for workers in the private sector. But recent reforms have exacerbated inequalities further.

INFONAVIT covers around 33 per cent of the workforce (IMSS), and FOVISSSTE 2 per cent (INEGI, 2014). As can be observed in Table 1, the proportion of loans granted by FOVISSSTE increased considerably during the last decade, and by 2012 more than 8 per cent of loans and more than 20 per cent of resources corresponded to that fund. In 2000, the average INFONAVIT loan was 19 per cent higher than the average FOVISSTE loan; but in 2012, the latter was 60 per cent higher (INEGI, 2013). Public sector workers, who represent a small minority of the workforce, have been receiving a disproportionate portion of housing spending, enabling them to access housing of much better quality than workers employed in the private sector.

There are also differences in the interest rates that INFONAVIT and FOVISSSTE affiliates pay. The annual rates are the same for workers earning the minimum wage, 4 per cent; but begin to differ after that level. At 1.6 times the minimum wage, INFONAVIT beneficiaries pay an annual rate of 4.2 per cent, whilst FOVISSSTE beneficiaries continue to pay 4 per cent up to a level of 2.5 times the minimum wage. At ten times the minimum wage, INFONAVIT affiliates pay a rate of 10 per cent, whilst FOVISSSTE affiliates pay only 6 per cent (LINFONAVIT, 1992; LISSSTE, 2007).

Recent inequalities between INFONAVIT and FOVISSSTE have been the by-product of the reform of the public sector's social insurance system. This reform increased employees' contribution rates and affected their pension rights (LISSSTE, 2007). In return for workers not opposing the reform, the government offered an increase on housing spending, among other perks (Tompson, 2009).

As INFONAVIT was stripped of its solidarity component (García Peralta, 2010), inequalities have also been preserved across workers of different income levels. The introduction of individual accounts and the points system to allocate INFONAVIT loans meant that fewer poor workers could obtain a loan (Puebla Cadena, 2006). CONAVI's subsidies were a response to these deficiencies, but their low level (CONAVI, 2012) suggests that, even if covered by a housing institute, low income workers can hardly accumulate enough resources to significantly improve housing standards.

\section{The failure of market mechanisms}

Market mechanisms have been placed at the centre of housing provision in recent decades. The institutionalisation phase of housing policy was marked by corruption, clientelism and a limited impact on the majority of the population. In tune with reforms in other policy areas, markets were seen as the solution to the country's housing problems. Market mechanisms were promoted on two fronts: funding and construction.

The lending frenzy on which commercial banks embarked between 1992 and 1994, eventually granting more loans than INFONAVIT, came to an end with the crisis of 1995 and contributed to their collapse (Connolly, 1997). The government then took the decision to boost private lending through the SOFOLs. By 2000, the private sector's participation in 


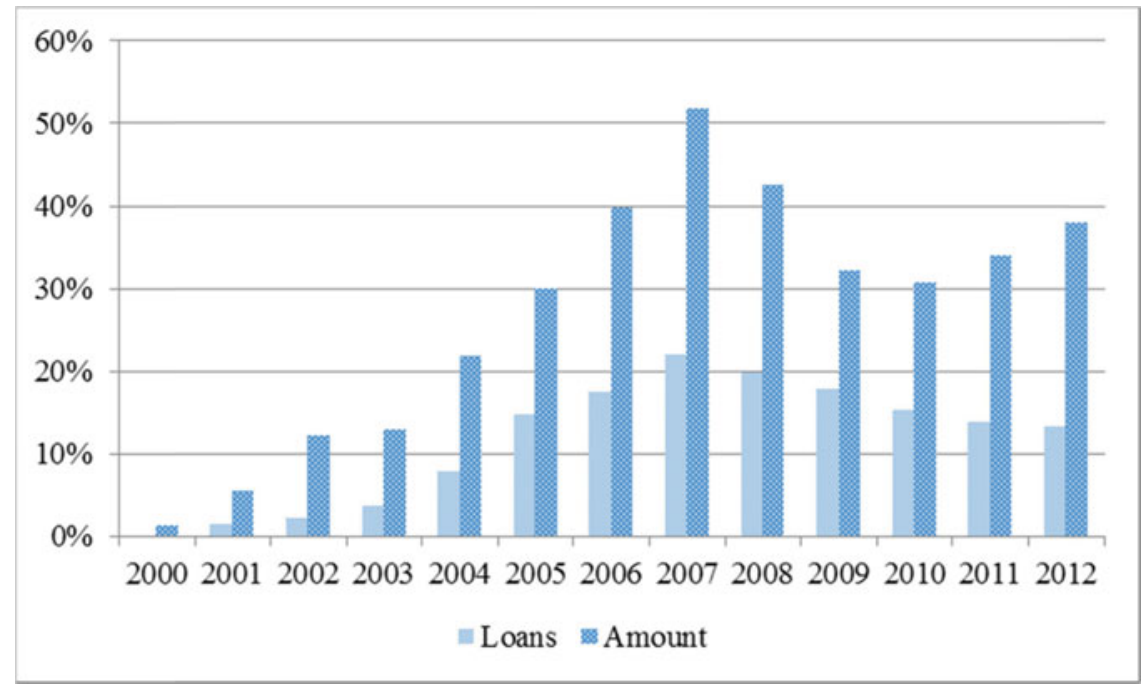

Figure 3. (Colour online) Private sector's loans and subsidies (\% of total) Source: INEGI (2012).

the funding of housing had practically disappeared following the collapse of commercial banks, representing less than 1 per cent and just over 1.5 per cent of the country's direct loans and funding, respectively. With the expansion of the SOFOLs, by 2007 the share had increased to 22 per cent of the loans and more than half of the funding (INEGI, 2012). These percentages are shown in Figure 3.

In the past, commercial banks had concentrated their lending on middle and upper income sectors, which constitute the minority of the workforce. After 2000, the aim became to extend the scope of market institutions towards the low income population; but the attempt failed. Figure 3 shows that the proportion of private sector loans decreased significantly after 2007 due to the collapse of the SOFOLs, which moved from granting 23,000 loans in 2008 to only 3,000 in 2011, and representing in this latter year less than 0.5 per cent of the total funding provided by private institutions (SHF/CIDOC, 2012). The levels of market intervention did not fall further because commercial banks continued providing loans to middle and upper income sectors (Herbert et al., 2012).

The main factor behind the demise of the SOFOLs was the lack of state regulation. The government took the conscious decision to renounce its regulatory obligations because it expected that the market would impose the necessary discipline on the SOFOLs (Herbert et al., 2012, SHF/CIDOC, 2012). But the prominent rule that the markets followed was that of maximising profits. The SOFOLs rapidly engaged in lending practices that led to their bankruptcy after the global financial crisis of 2008. By the end of the period the few SOFOLs that were still operating relied exclusively on government funding (Herbert et al., 2012). The story is similar to that of 1995, when the government had to step in to rescue private banks.

The vacuum in the funding of adequate housing for low income families continues to be unfilled. Private sector loans remain inaccessible for households with earnings of up to four times the minimum wage (SHF/CIDOC, 2012), the income bracket into which 40 per 
cent of households in the country fall (ENIGH, 2010). The market imposes unbridgeable restrictions such as high income thresholds to qualify for a loan, and high interest rates and down payments (Puebla Cadena, 2006; Bredenoord and Verkoren, 2010). The levels of mortgage debt have not risen as much as in other countries; in 2009 it was estimated at 14 per cent of Gross Domestic Product (GDP) (SHF/CIDOC, 2009). But, as discussed, this is not because the state has not tried to increase mortgage lending, but because of the failure of its market-centred model.

The second front opened by the state to promote markets was the funding of private construction companies, carried out by SHF with the SOFOLs acting as intermediaries. As in the case of mortgage lending, at the beginning the initiative seemed to be producing good results. The proportion of housing within the construction industry increased from 17 per cent in 2000 to 32 per cent in 2007 (Herbert et al., 2012). However, the absence of state regulation would also cause serious problems.

The withdrawal of the public housing funds from the planning of housing production (Puebla Cadena, 2006; García Peralta, 2010), combined with historically weak oversight functions by the federal and local governments (Herbert et al., 2012), meant that the state tacitly left the planning of the supply of housing to private constructors. Constructors could count on abundant funding offered by the state, through the SHF and the SOFOLs, but in order to maximise their profits they ended up flooding the market with badly located homes far from urban centres, and in some cases of low quality too. Housing demand fell rapidly; it was estimated that by 2011 there were around 4.6 million uninhabited homes in urban areas, many of them due to their inconvenient location and lack of access to public services (SHF/CIDOC, 2011). As happened with the SOFOLs, most of the large constructors that boomed during the first years of the century were, or close to, declaring bankruptcy (SHF/CIDOC, 2012).

Housing has been described as the wobbly pillar of the welfare state because of its reliance on markets (Kemeny, 2006). Private sector participation in housing is frequently higher than in other social policy areas, but in Mexico the market rationale was seen as the ultimate solution to the country's historic housing problems. Liberal politicians and policy-makers have been promoting market alternatives in all policy areas for more than twenty years (Teichman, 2002; Rodríguez Araujo, 2010). The tendency is evident not only in housing, but also in pensions, with the privatisation of social insurance systems, or in anti-poverty policy, where conditional cash transfers of minimal amounts have the foremost objective of reducing poverty through labour market participation (Bayón, 2009). The outcomes however, are not optimal. Far from it, the prioritisation of market solutions by the state has generated additional problems of its own.

The reliance on familistic arrangements

Home ownership rates have been traditionally higher in Mexico than in many other countries. In the early 1990s few European countries had a rate higher than 60 per cent, whilst in Mexico it was close to 80 per cent, as shown in Figure 4. There are two causes for this high ratio. On the one side, the aim of public policy since the 1970s has been to support home ownership by providing loans or subsidies, undoubtedly having an effect on the type of tenure. However, considering the unequal features of housing policy and markets' failures, it is familistic arrangements which explain the high numbers of Mexican who inhabit their own homes. 


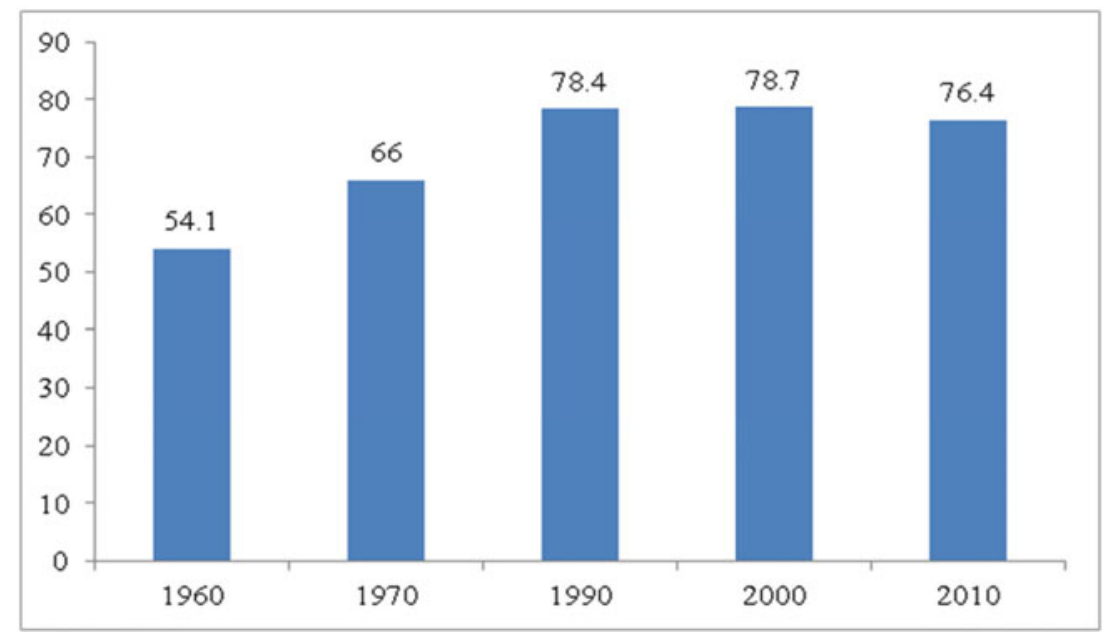

Figure 4. (Colour online) Home ownership rate in Mexico, 1960-2010

Source: INEGI (2013).

The majority of families have obtained their land and built their homes with their own resources. It has been estimated that between the 1940s and 1970s the combined efforts of public policy initiatives and market instruments amounted to only 35 per cent of housing production, and that the remaining 65 per cent were homes that families built mobilising their own resources (Bredenoord and Verkoren, 2010). By 2010, between 50 and 60 per cent of all homes in the country had been built by families using their own resources, and every year 40 per cent of new homes were built without any government or market support (SHF/CIDOC, 2010).

The problem for poor families is that self-built homes often result in long construction periods, higher costs, and homes of low quality (SHF/CIDOC, 2012). By 2012, the housing deficit, that is the number of homes considered in need of replacement because they are built with precarious materials and/or overcrowded, was estimated at 9 million, 32 per cent of the national total. It was also estimated that given their low income level and the labour market attachment of earners, only 7 per cent of families living in those homes could demand a new home through government programmes or private financial markets (SHF/CIDOC, 2010). Current state-market arrangements fail to offer alternatives for the majority of families in the country.

Nonetheless, home ownership does represent an important source of welfare for Mexican families. Considering that social insurance pensions cover less than one quarter of the elderly population, and that families can only receive income support through targeted conditional cash transfers of minimal amounts insufficient to raise living standards in a significant way (Damián, 2007; Bayón, 2009), home ownership represents one of the pillars of social protection, as in other semi-peripheral countries (Castles and Ferrera, 1996; Allen et al., 2004; Ferrera, 2005).

These types of welfare arrangements, and in particular the need and ability of families to mobilise their own resources to access housing, resemble what Papadopoulos and Roumpakis (2013) call a familistic welfare regime, where the family plays the dual 
role of main welfare provider and key agent for the reproduction of politico-economic institutions. These regimes are characterised by a segmented, unequal and exclusionary social protection system; a political regime based on clientelistic and corporatist relations; a dual labour market with a large informal sector; and a capitalist economy dominated by oligopolies connected to political elites (Ferrera, 1996; Papadopoulos and Roumpakis, 2013).

Mexico fits into this depiction, notwithstanding that, as in similar semi-peripheral countries, the nature of state/markets-family relations has been transformed during the past two decades (Papadopoulos and Roumpakis, 2013). The case of housing, as analysed in this article, illustrates such transformation. During the first two phases of housing development between the 1930s and the 1980s, families mainly interacted with state structures. Markets were adequate to deliver housing for upper class segments. For the majority of poor families, which provided the workforce for the capitalist development of the country, relations with the state evolved from a stage when an engagement in clientelistic arrangements was necessary to acquire a piece of land, regularise land titles and obtain public services, to a more institutionalised stage, where affiliation to corporatist institutions provided the key to obtaining a housing loan from the government. In both stages families had to mobilise their economic and political resources to access housing, whilst housing arrangements guaranteed the reproduction of the hegemonic party regime and an economic strategy based on the development of domestic industries.

Market-family relations gained importance during the last phase. Housing policy has been expanded but with a market rationale. Access to housing now depends to a larger extent on the family's market income and its capacity to contract debt. In addition, targeted subsidies complement the political regime and economic model by supplementing low earnings. Because of their minimal levels, they fail to offer comprehensive housing solutions; but along with other targeted programmes they would be helping to legitimise the pluralist democratic regime by offering at least some benefits to the poor, whilst serving an export-oriented economic model, by keeping labour costs and social spending under control, with the aim of raising the competitiveness of the country.

Both modes of state/market-family relations have produced poor outcomes in terms of the funding available for, and the quality of, housing. In the past, corporatist and clientelistic practices resulted in the exclusion of large sectors of the population. Under the current market-oriented model, housing funding and production have increased, but the country's historic housing problems have not been resolved, whilst additional weaknesses and risks have been created that limit the impact of public policy on the welfare of the majority of the population.

\section{Concluding remarks}

The development of the Mexican housing regime illustrates the evolution of welfare provision in the country. From the onset of the hegemonic party regime until the beginnings of economic and political liberalisation, state intervention in the housing sector was based to a large extent on corporatist/clientelistic arrangements that had an unequal and limited impact on the housing standards of the majority of the population; simultaneously serving the state's industrialisation strategy and helping to maintain political and social stability. 
In the 1990s the government reformed the housing sector under a market rationale, with the expectation of solving the country's housing problems. Initially the marketcentred model did increase housing production and financing, but the reforms did not correct the unequal and fragmented nature of the country's social policy. Moreover, market forces generated additional problems and created high barriers for access to housing by large parts of the population.

Social policy in Mexico has been dominated by a market-centred ideology for the past two decades. As illustrated in this article by the example of housing, the outcomes have not been good. The literature on this country could benefit from further research on the political, economic and social drivers of market-centred reforms, in order to identify the mechanisms that could bring changes that would result in a more egalitarian and redistributive social policy.

\section{Acknowledgements}

The author would like to thank Antonios Roumpakis, Theo Papadopoulos, Dominic Mitchell and the two anonymous reviewers for their valuable comments on previous versions of this article.

\section{Notes}

1 More recent reforms could suggest that some countries in the region have moved towards a socialdemocratic model (Huber and Stephens, 2012), but this would not be the case of Mexico, where social policy changes have been based on liberal principles (Bayón, 2009; Dion, 2010).

2 The average annual population growth rate passed from 1.8 per cent in the 1930 s to 3.4 per cent in the 1960s, and the urban population doubled from 34 per cent in 1930 to 59 per cent in 1970 (INEGI, 2013).

3 Mexico was hit hard by the crisis, GDP fell 4.7 per cent in 2009 (World Bank, 2013).

\section{References}

Alcock, P., Erskine, A. and May, M. (2003) The Student's Companion to Social Policy, Oxford: Blackwell. Allen, J., Barlow, J., Leal, J., Maloutas, T. and Padovani, L. (2004) Housing and Welfare in Southern Europe, Oxford: Blackwell.

Babatz, G. (2004) 'The role of the Sociedad Hipotecaria Federal in the development of the Mexican mortgage market', paper presented at the XLI Inter-American Conference for Housing, Panama City, 11-13 August.

Barba, C., Ordonez, G. and Valencia, E. (2007) 'La reforma social del Estado en Mexico', in J. L. Calva (ed.), Agenda para el desarrollo vol. 11, Empleo, ingreso y bienestar, México, DF: Miguel Angel Porrúa, pp. 280-311.

Barrientos, A. (2004) 'Latin America: towards a liberal-informal welfare regime', in I. Gough and G. Woods (eds.), Insecurity and Welfare Regimes in Asia, Africa and Latin America, Cambridge: Cambridge University Press, pp. 121-68.

Barrientos, A. (2009) 'Labour markets and the (hyphenated) welfare regime in Latin America', Economy and Society, 38, 1, 87-108.

Bayón, M. C. (2009) 'Persistencia de un modelo social excluyente en México', Revista Internacional del Trabajo, 128, 3, 331-47.

Brachet-Márquez, V. (2007) 'Mexico's welfare state: birth, growth and retrenchment (1822-2002)', in M. Riesco (ed.), Latin America: A New Developmental Welfare State Model in the Making?, New York: United Nations Research Institute for Social Development (UNRISD), pp. 117-47. 
Brachet-Márquez, V. and De Oliveira, O. (2002) 'Mujer y Legislación Social Mexicana', Estudios Sociológicos, 20, 3, 537-81.

Bredenoord, J. and Verkoren, O. (2010) 'Between self-help and institutional housing: a bird's eye view of Mexico's housing production for low and (lower) middle-income groups', Habitat International, 34, 3, 359-65.

Carrillo Castro, A. (1987) 'EI ISSSTE: La salud y la seguridad social para los trabajadores al servicio del Estado', Revista de Administración Pública, 69-70.

Castles, F. and Ferrera, M. (1996) 'Home ownership and the welfare state: is southern Europe different?', South European Society and Politics, 1, 2, 163-85.

CEPAL (2013) Gasto Social en América Latina y el Caribe: Estadísticas, Santiago de Chile: Comisión Económica para América Latina y el Caribe, http://dds.cepal.org/gasto/indicadores/\#: [accessed 30.09.2014].

CIDOC (2004) El Estado de la Vivienda en México, México, DF: Fundación Centro de Investigación y Documentación de la Casa, A.C/Comisión Nacional de Fomento a la Vivienda.

CONAVI (2012) Reglas de Operación del Programa 'Esta es tu Casa', México, DF: Comisión Nacional de Vivienda.

CONAVI (2013) Informe de Autoevaluación del Director General de la CONAVI 2012, México, DF: Comisión Nacional de Vivienda.

Connolly, P. (1997) 'El Financiamiento Habitacional en México', in E. Harrasti and J. Villavicencio (eds.), La política habitacional en México y América Latina, México DF: Universidad Autonóma MetropolitanaAzcapotzalco.

Damián, A. (2007) 'Los retos en materia social en México a inicios del siglo XXI', in J. L. Calva (ed.), Agenda para el desarrollo vol. 11, Empleo, ingreso y bienestar, México, DF: Miguel Angel Porrúa-UNAM.

De Gortari, H. and Ziccardi, A. (1996) 'Instituciones y clientelas de la política social: un esbozo histórico, 1867-1994', in Las políticas sociales de México en los años noventa, Mexico, DF: Universidad Nacional Autonóma de México/Facultad Latinoamericana de Ciencias Sociales/Plaza y Valdés, pp. 201-34.

De Pablo, L. (2000) 'La política de vivienda en México', Crónica Legislativa, 13, 8-12.

Diaz-Cayeros, A., Estévez, F. and Magaloni, B. (2012) Strategies of Vote Buying: Democracy, Clientelism and Poverty Relief in Mexico, unpublished book manuscript, Stanford University.

Dion, M. (2010) Workers and Welfare: Comparative Institutional Change in Twentieth-Century Mexico, Pittsburgh: University of Pittsburgh Press.

ENIGH (2010) Encuesta Nacional de Ingresos y Gastos de los Hogares, Tabulados básicos: Instituto Nacional de Estadística y Geografía (INEGI), http://www3.inegi.org.mx/sistemas/ tabuladosbasicos/tabdirecto.aspx? $\mathrm{s}=\mathrm{est} \& \mathrm{c}=33493$ : [accessed 30.09.2014].

Ferrera, M. (1996) 'The "Southern model" of welfare in Europe', Journal of European Social Policy, 6, 1, $17-37$.

Ferrera, M. (2005) 'Welfare states and social safety nets in Southern Europe: an introduction', in M. Ferrera (ed.), Welfare State Reform in Southern Europe, Oxford: Routledge.

Filgueira, C. and Filgueira, F. (2002) 'Models of welfare and models of capitalism: the limits of transferability', in E. Huber (ed.), Models of Capitalism: Lessons for Latin America, Pennsylvania: The Pennsylvania State University Press.

Garcia Peralta, B. (2010) 'Vivienda social en México (1940-1999): actores públicos, económicos y sociales', Cuadernos de Vivienda y Urbanismo, 3, 5, 34-49.

Hansen, R. (1971) La politica del desarrollo mexicano, Mexico, DF: Siglo Veintiuno Editores.

Herbert, C., Belksy, E. and Dubroff, N. (2012) The State of Mexico's Housing - Recent Progress and Continued Challenges, Cambridge, MA: Joint Center for Housing Studies, Harvard University.

Huber, E. and Stephens, J. (2012) Democracy and the Left: Social Policy and Inequality in Latin America, Chicago, IL: The University of Chicago Press.

IMSS (2013) Memoria Estadística, México, DF: Instituto Mexicano del Seguro Social (IMSS). 
INEGI (2010) Estadísticas históricas de México 2009, Aguascalientes: Instituto Nacional de Estadística y Geografía.

INEGI (2012) Anuario Estadístico de los Estados Unidos Mexicanos 2012, Aguascalientes: Instituto Nacional de Estadística y Geografía.

INEGI (2013) Estadística: Población, Hogares y Vivienda, Aguascalientes: Instituto Nacional de Estadística y Geografía, http://www3.inegi.org.mx/sistemas/temas/default.aspx?s=est\&c=17484: [accessed 30.09.2014].

INEGI (2014) Estadísticas de informalidad laboral, Aguascalientes: Instituto Nacional de Estadística y Geografía.

Kemeny, J. (2006) 'Corporatism and housing regimes', Housing, Theory and Society, 23, 1, 1-18.

Langston, J. (2002) 'Los efectos de la competencia electoral en la selección de candidatos del PRI a la Cámara de Diputados', in C. Elizondo Mayer-Serra and B. Nacif (eds.), Lecturas sobre el cambio político en México, México, DF: Centro de Investigación y Docencia Económicas (CIDE)/Fondo de Cultura Económica (FCE).

LINFONAVIT (1992) Ley del Instituto Nacional del Fondo Nacional de la Vivienda para los Trabajadores, México, DF: Instituto Nacional del Fondo Nacional de la Vivienda para los Trabajadores (INFONAVIT).

LISSSTE (2007) Ley del Instituto de Seguridad y Servicios Sociales de los Trabajadores del Estado, Mexico, DF: Instituto de Seguridad y Servicios Sociales para los Trabajadores del Estado (ISSSTE).

Martínez, F. (2003) 'Se esfumaron de Infonavit cuotas de millones de trabajadores', La Jornada, 8 April.

Mesa-Lago, C. (2000) Desarrollo social, reforma del Estado y de la seguridad social, al umbral del siglo XXI, Serie Políticas Sociales, Santiago de Chile: Comisión Económica para América Latina y el Caribe (CEPAL).

Molyneux, M. (2006) 'Mothers at the service of the new poverty agenda: Progresa/Oportunidades, Mexico's conditional transfer programme', Social Policy and Administration, 40, 4, 425-49.

Norris, M. and Winston, N. (2012) 'Home-ownership, housing regimes and income inequalities in Western Europe', International Journal of Social Welfare, 21, 2, 127-38.

Paladino, M. (2010) Intermediación clientelar de demandas sociales y mobilización política. La vivienda social en la ciudad de México, Doctorado de Investigación en Ciencias Sociales con Mención en Sociología, Facultad Latinoamericana de Ciencias Sociales (FLACSO), Sede Académica de México.

Papadopoulos, T. and Roumpakis, A. (2013) 'Familistic welfare capitalism in crisis: social reproduction and anti-social policy in Greece', Journal of International and Comparative Social Policy, 29, 3, $204-24$.

Platt, H. L. (2010) 'Exploding cities: housing the masses in Paris, Chicago, and Mexico City, 1850-2000', Journal of Urban History, 36, 5, 575-93.

Puebla Cadena, C. (2006) Las instituciones públicas de vivienda en México. La vivienda en México. Construyendo análisis y propuestas, México, DF: Centro de Estudios Sociales y de Opinión Pública (CESOP), Cámara de Diputados.

Rodriguez, A. and Maycock, C. (2006) 'The constitution of private property: a comparative analysis of US and Mexico housing policies', International Journal of Public Administration, 29, 13, 1195-213.

Rodríguez Araujo, O. (2010) 'The emergence and entrenchment of a new political regime in Mexico', Latin American Perspectives, 37, 1, 35-61.

Shefner, J. (2001) 'Coalitions and clientelism in Mexico', Theory and Society, 30, 5, 593-628.

SHF/CIDOC (2009) Estado Actual de la Vivienda en México 2009, México, DF: Sociedad Hipotecaria Federal/Fundación Centro de Investigación y Documentación de la Casa, A.C.

SHF/CIDOC (2010) Estado Actual de la Vivienda en México 2010, México, DF: Sociedad Hipotecaria Federal/Fundación Centro de Investigación y Documentación de la Casa, A.C.

SHF/CIDOC (2011) Estado Actual de la Vivienda en México 2011, México, DF: Sociedad Hipotecaria Federal/Fundación Centro de Investigación y Documentación de la Casa, A.C.

SHF/CIDOC (2012) Estado Actual de la Vivienda en México 2012, México, DF: Sociedad Hipotecaria Federal/Fundación Centro de Investigación y Documentación de la Casa, A.C. 
Teichman, J. (2002) 'Private sector power and market reform: exploring the domestic origins of Argentina's meltdown and Mexico's policy failures', Third World Quarterly, 23, 3, 491-512.

Tompson, W. (2009) 'Mexico: reform of the federal employee's pension system, 2001-07', in W. Tompson and R. Price (eds.), The Political Economy of Reform: Lessons from Pensions, Product Markets and Labour Markets in Ten OECD Countries, Paris, France: Organisation for Economic Co-operation and Development (OECD).

World Bank (2013) World Development Indicators, Washington, DC: World Bank http://data.worldbank. org/data-catalog/world-development-indicators [accessed 30.09.2014]. 